the figures produced by fine dust on the surfaces of electrified plane surfaces. His electrical experiments led to a correspondence with Volta. Lichtenberg was also well known as a friend of Garrick and a writer on Hogarth.

Albert Ladenberg was born on July 2, 1842, at Mannheim, his parents being Jews. From Karlsruhe Polytechnic he, went to Heidelberg to work under Bunsen and Kirchhoff, and he afterwards worked with Kekulé at Ghent and with Wurtz and Friedel in Paris. In 1872 he was appointed professor of chemistry at Kiel, and it was there that he began his important researches on vegetable alkaloids. In 1889 he became professor of chemistry in the University of Breslau and he held this position until 1909. He died on August 15, 1911. While yet a privatdocent, Ladenburg began to lecture on the history of chemistry, and during the space of forty years various editions of his "History of the Development of Chemistry during the past 100 Years" appeared in German, French and English. In Great Britain he was awarded the Davy Medal of the Royal Society and the Hanbury Medal, and was made an honorary member of the Chemical Society. A memorial lecture on his life and work was delivered to the Chemical Society by Dr. Kipping on October 23, 1913.

\section{Mineral Resources and the Atlantic Charter}

ThE Conference on "Mineral Resources and the Atlantic Charter", arranged by the Division for the Social and International Relations of Science of the British Association, is to be held in the theatre of the London School of Hygiene and Tropical Medicine, Keppel Street, Bloomsbury, London, on July 24 and 25. There will be morning and afternoon sessions on each day, beginning at 10 a.m. and 2.15 p.m. The subjects of the successive sessions are intended, broadly speaking, to be classified respectively as: (1) distributional, in the geological and geographical aspects; (2) the preceding considerations as applicable to certain mineral products; (3) new sources and materials; (4) economic and planning considerations. The Conference will be opened by Sir Richard Gregory, president of the Association, and the chair at the successive sessions will be taken by Sir Thomas Holland, Sir William Larke, Dr. C. H. Desch and the Right Hon. Sir Stafford Cripps. Among expected speakers are Prof. H. H. Read, Prof. C. B. Fawcett, Prof. W. R. Jones, Sir Lewis Fermor, Dr. E. F. Armstrong, Dr. W. H. Hatfield, Dr. L. Dudley Stamp and Prof. J. G. Smith. Admission to the Conference will be by ticket, obtainable from the British Association, Burlington House, London, W.1 ; tickets will be issued, so far as accommodation in the theatre permits, on or after July 13.

\section{Psychology of Hate}

Dr. ERICH Fromm, in a recent report to the Journal of the American Home Economics Association, discussed the two kinds of hatred which he claims exist. One is what he calls the "counterpoint of life". It is rational hatred, aroused by an attack on life, freedom, country, some person or institution we love. Such hatred is necessary for winning a war against aggression. "People must love what they are defending, in order to hate their attackers effectively." The other kind of hatred, which he calls "characterconditioned", was made use of by the Nazis in recruiting their party. The bulk of their recruits came from the lower middle class, who had led a starved and frus. trated life socially and economically, pas cularly since 1918, in Germany. This led to tremendous irrational hatred and destructiveness which could only be expressed in small doses before the Nazi party offered an outlet.

"Destructiveness", says Dr. Fromm, "is the result of unlived life." He believes that this kind of irrational or character-conditioned hatred, which is all too common in our culture, results from the blocking of spontaneity and self-expression in childhood. Parents and teachers have many ways of discouraging self-development in children, from open intimidation to the subtle, 'sweet' type of authority which does not forbid, but says "I know you won't want to do that". Such children grow up with so little confidence in their own wishes and emotions that they can neither love nor hate constructively. Always dependent on other people even for their opinions, they are ready to follow a leader blindly. Their apparent submissiveness hides a dangerous amount of sadistic aggression, ready to be unleashed at the command of a Führer. But Dr. Fromm believes that this irrational hatred, utilized by the Germans, Italians and Japanese, is much less effective for winning wars than the positive kind of savagery shown by the Chinese and the Russians in defending their homes. The latter kind of hatred arises only when people are fighting for something they love. While Nazism pretends to fight for the life and existence of the German people, it is basically a movement of nihilism profoundly attracted by destruction. Its motto was adequately expressed by a speech once made by a Fascist officer who ended : "Long live death".

\section{Broadcasts on American Thought and Culture}

A NEW series of short-wave broadcasts under the auspices of the American Philosophical Society was inaugurated on April 24 over the non-commercial short-wave radio station WRUL. The world-wide significance of American thought and achievement in the present crisis in our civilization will form the general background of the series; distinguished American authorities will deliver a series of addresses, each in his special field-scientific, sociological and cultural. The American Philosophical Society and the World Wide Broadcasting Foundation have arranged to send out this series of short-wave broadcasts over WRUL from the Society's Hall in historic Independence Square, Philadelphia. They will be directed primarily to countries overseas where the English language is spoken and understood, and where there is still interest in the progress of science and learning and faith in a democratic form of government. WRUL is planning to translate a number of these outstanding talks into other languages for many of the countries covered by its beams; the station now broadcasts in twenty-two languages.

\section{The John Innes Horticultural Institution}

The report of the thirty-second year of the John Innes Horticultural Institute covers the activities during 1942. A considerable number of changes of staff, including the resignations of such well-known individuals as C. Pellew, D. de Winton and B. Schafer, have taken place. Many of the staff have left to take up Government work. In addition, a serious drop in income as a result of war damage to 